\title{
Per peccatum cecidit diabolo faciente: On the causal/instrumental uses of "faciente + (pro)noun" in imperial and late Latin*
}

\section{Giovanbattista Galdi}

University of Ghent,

Blandijnberg 2, 9000 Ghent (Belgium); giovanbattista.galdi@ugent.be

For citation: Giovanbattista Galdi. Per peccatum cecidit diabolo faciente: On the causal/instrumental uses of "faciente + (pro)noun" in imperial and late Latin. Philologia Classica 2019, 14(1), 89-106. https://doi.org/10.21638/11701/spbu20.2019.107

This present paper is concerned with the causal/instrumental uses of faciente + (pro)nominal head within an ablative absolute. We only examine the instances in which the participle does not govern a direct object and is not accompanied by further arguments and/or satellites, as in Jer. In psalm. 89 l. 28 qui per peccatum cecidit, diabolo faciente, rursum per Christum resurgat ad gloriam ("he who fell through sin under devil's influence, shall soon be reborn to the Glory through Christ"). The analysis is restricted to the imperial and late period because the construction is not attested until Ovid (Met. 2, 540-541 lingua faciente loquaci / qui color albus erat, nunc est contrarius albo "through his tongue's fault the talking bird, which was white, was now the opposite of white", transl. Loeb). The discussion consists of four main sections. After a short survey of the main studies on the topic, we introduce the analysed corpora, the selection criteria of the data and the overall results. In section 5 we discuss some possible reasons behind the origin of the syntagm. Subsequently, the use and expansion of the syntagm in later centuries is analysed in the light of recent studies on the reanalysis of participles as prepositions. We show that faciente began a categorial shift into the class of causal/instrumental prepositions, but for reasons that shall be explained, this process remained unaccomplished. In the last section, we make a brief comparison with other absolute ablatives that include semantically related participles (operante, instigante, praestante), pointing out the main differences between them.

Keywords: Late Latin, Christian Latin, categorial reanalysis, transcategorization, grammaticalization, participles, deverbal prepositions, ablative absolute, semantic bleaching, facere.

* The author wishes to express his personal gratulations to Prof. Alexander Verlinsky on his $60^{\text {th }}$ anniversary.

(C) St. Petersburg State University, 2019 


\section{Previous studies on faciente}

Starting from Ovid's often quoted verses, Met. 2, 540-541: lingua faciente loquaci / qui color albus erat, non est contrarius albo ("through his tongue's fault the talking bird, which was white, was now the opposite of white", transl. Loeb), one encounters several times in Latin a special use of faciente + (pro)nominal head not accompanied by further arguments and/or satellites and bearing nearly systematically causal/instrumental force. The first scholar to mention these uses was Heraeus in his well-known study on Petronius' language (1899, 36 n. 2) and, more in detail, in a later paper (1903), where he regards it as a characteristic late Latin phenomenon ${ }^{1}$. Similarly, a few years later, the construction is referred to by Löfstedt $(1911,167)$ in connection with the expansion of facio in late Latin sources $^{2}$. Horn $(1918,37)$ reports several examples in a chapter dealing with the formulaic absolute ablatives and Flinck-Linkomies $(1929,220-221)$ inserts it within the more general discussion of present participles governed by inanimate nouns. The monumental facio-lemma in the Thesaurus Linguae Latinae devotes a whole paragraph to the idiom (TLL VI, 123, 52-64), quoting further instances, and a brief mention is also found in Hofmann, Szantyr (1972, 133-134). Despite the initial interest, though, this use has been entirely neglected over the last 50 years, leaving aside a few remarks in commentaries of late texts ${ }^{3}$.

\section{Analysed corpora and general results}

Our investigation is based on Brepol's Library of Latin Texts A and B, from which we considered all the sub-corpora included between the beginning of Latin literature and the end of the $8^{\text {th }}$ century $\mathrm{AD}^{4}$. These data have been integrated on the one hand with the two on-line databases Corpus Corporum (University of Zürich) and Digital library of late-antique latin texts (University of Eastern Piedmont) ${ }^{5}$, on the other hand, with all passages quoted in scholarly literature, including the TLL-lemma. Additionally, we consulted the main electronic corpora of non-literary Latin texts ${ }^{6}$ and, for the Merovingian period, we referred to the PaLaFra corpus ${ }^{7}$ and to the Leges Antiquiores included in the Monumenta

1 "Die Umschreibung mit faciente zur Bezeichnung der Urheberschaft, der Veranlassung, des Beweggrundes uä ist dem Spätlatein eigenthümlich" $(1903,466)$. In this paper, Heraeus also observes that in some cases ancient manuscripts and modern editions erroneously normalize faciente with other, more 'classical' verbal forms, such as fauente. Cf. also Kortekas $(2007,124)$.

${ }^{2}$ Specifically, referring to Act. Achat. 4 p. 118, 29 non hominum more deus filium ex muliebri coitu genuit, sed Adam primum dextera sua faciente formauit ("God did not generate his son from a woman by intercourse, as humans do, but first created Adam with his right hand”), Löfstedt $(1911,167)$ remarks that faciente "fast gänzlich zur Bedeutung von 'durch', 'mit' herabgesunken ist".

${ }^{3}$ Cf. for instance Kortekas $(2007,124)$ and Panayotakis $(2012,163)$ in relation to the Historia Apollonii.

4 These are: (a) Antiquitas (until 200 AD), (b) Aetas Patrum I (ca. 200-500), (c) Concilia oecumenica et generalia Ecclesiae catholicae (mainly $6^{\text {th }}-8^{\text {th }} \mathrm{c}$.), (d) Biblia sacra iuxta Vulgatam (ca. $4^{\text {th }}-5^{\text {th }} \mathrm{c}$.) and (e) Aetas Patrum II (501-735).

${ }^{5}$ See http://www.mlat.uzh.ch/MLS/ and http://digiliblt.lett.unipmn.it/.

${ }^{6}$ For the inscriptions, we searched the Epigraphic-Datenbank clauss-Slaby (http://www.manfredclauss. de/) and the Epigraphic Database Heidelberg (https://edh-www.adw.uni-heidelberg.de/home? \&lang=en). For the papyri, we referred to the papyrological Navigator (http://papyri.info/). Additionally, we explored all the curse tablets edited in the CD attached to Kropp's monograph (2008).

${ }^{7}$ Cf. http://txm.bfm-corpus.org/?command=documentation\&path=/BFM2016. 


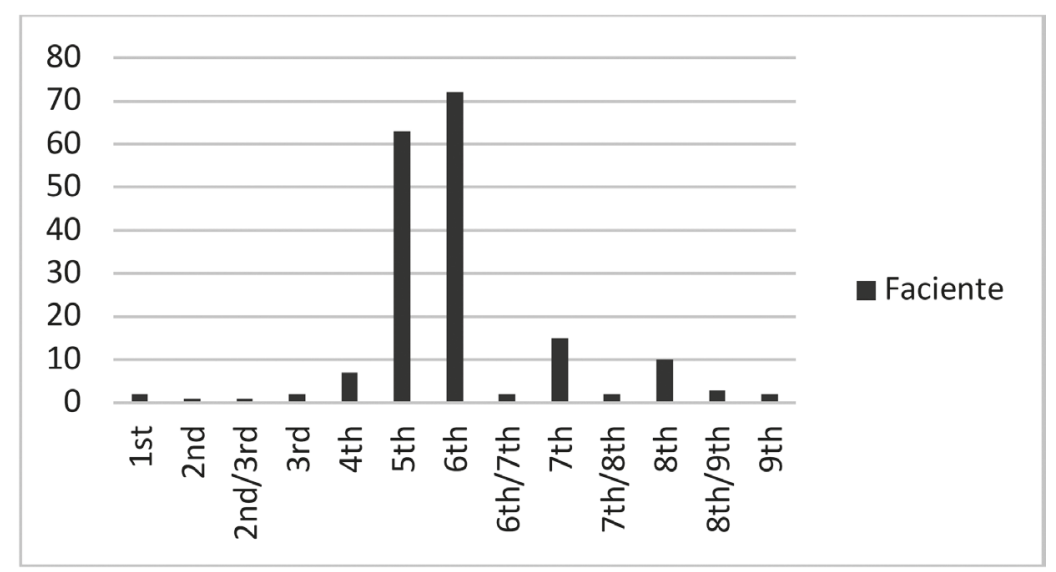

Fig. 1. Diachronic distribution of faciente

Germaniae Historica ${ }^{8}$. In this way, we could achieve an almost complete picture of the phenomenon and of its diffusion over the entire antiquity.

The focus of the research lies on the instances in which faciente, typically displaying instrumental or causal function, undergoes semantic bleaching and a partial transcategorization from participle to preposition can be assumed (see section 5). To this purpose, we excluded all instances in which the participle syntactically preserves its verbal function, being determined by an adverb or a prepositional phrase, ${ }^{9}$ e.g.

(1) idcirco te post dominum faciente damnatus est, quod ausus sit perpetuae castitati matrimonium conparare (Jer. Ep. 49, 2)

"On this ground he has been damned, while you were acting according to the Lord, because he dared to compare the marriage with perpetual chastity."

The analysis revealed a relatively spread use of the construction (182 examples). The diachronic distribution is though uneven, as shown in figure 1.

The syntagm starts to expand around the $4^{\text {th }} \mathrm{c}$., reaches its peak in the $5^{\text {th }}$ and $6^{\text {th }} \mathrm{c}$., and drastically drops in the following period, ${ }^{10}$ though never entirely disappearing from written language (several examples are attested in late medieval authors). Although Horn, as seen above, classifies the pattern among the "formelhafte Ablativi Absoluti" (Horn $1918,35-39)$, the number of nouns involved is remarkably high (100 in total) and the vast majority of them is found only once (69 times) or twice (15 times), which rather

${ }^{8}$ Cf. https://www.dmgh.de/.

9 There are only five such cases, one of which is moreover ambiguous because the prepositional cluster (apud Baias) may refer, by hyperbaton, to the main predicate. See (19) below. On the other hand, we retained 21 occurrences in which facio (or fio) is employed within the same sentence and therefore we cannot rule out that, at least in some of them, faciente preserves its standard meaning of "doing", "making" etc. Such instances are particularly common in Augustine.

${ }^{10}$ Note that the diachronic distribution cannot be accounted for by the date of the analysed texts. For, based on the works included in Brepol's database, which constitute the great bulk of our corpus, one would rather expect a peak of occurrences in the $4^{\text {th }}$ and $5^{\text {th }}$ century (414 and 483 texts, respectively) and a much lower incidence in the $6^{\text {th }} \mathrm{c}$. (289 works). 
speaks against a formulaic use. ${ }^{11}$ A significant variety can also be observed in relation to the literary domains. Expectedly, Christian texts dominate, notably those of theological and exegetic nature (38 instances were found in the commentaries of holy writings). ${ }^{12}$ The syntagm, however, is also well represented in juridical sources, narrative prose and in the scholiasts (cf. also Heraeus 1899, 167). ${ }^{13}$ As for the diaphasic and diastratic axis, it is striking that texts typically associated with popular or substandard Latin, such as the Itinerarium Egeriae and the Mulomedicina Chironis provide no examples of the construction. ${ }^{14}$ The same is true for nearly all documentary sources included in the corpus (inscriptions, curse tablets, papyri). Moreover, the great majority of the texts adopting the syntagm, and particularly those in which it figures several times cannot be classified as stylistically low (see for instance Cassiod. In psalm., August. De civ. D. and In psalm.). We might hence argue ex silentio that this use was not common in ordinary speech, especially in lower varieties. However, due to its emergence in Augustine's Sermones - cf. (20) below -, in late juridical texts and, above all, in a $6^{\text {th }}$ century papyrus from Ravenna - see (3), (4) - we cannot rule out the possibility that this use gained some currency even in spoken language. Additionally, it should be noted that about the half of the occurrences are found within exegetic (both Christian and pagan) or prescriptive texts (see n. 12). Since such works aim at explaining texts and giving rules and are thus in principle characterized by the clarity of the language, we must assume that this special use of facio did not generate ambiguity in the reader. ${ }^{15}$

\section{On the origin of the syntagm}

Despite the large amount of studies discussing or mentioning the phenomenon, almost none of them attempted to give an explanation to its origin. The only exception is represented by Flinck-Linkomies' monograph $(1929,220-221)$. He sees the starting point in the general decrease of frequency of nominal ablative absolutes, such as aliquo auctore, adiutore, hortatore etc., which would eventually lead to their total disappearance in late Latin. They were first replaced by expressions as aliquo adiuuante, hortante, suadente etc., already admitted in classical Latin, and then by aliquo faciente that, according to the author, constitutes the exact pendant of auctore aliquo. In support of his theory, FlinckLinkomies $(1929,221)$ quotes a passage from Lucifer Calaritanus where faciente Deo could easily be replaced by auctore Deo:

11 The highest incidence emerges with casus, Deus (both 10 times), and necessitas (9 times). Conversely, with the semantically contiguous participles operante, instigante and praestante the frequency of individual clusters is much higher (see below section 6).

12 The high frequency in Christian sources cannot be ascribed to (or influenced by) the Bible, as it is often the case in Christian literature (see Adams 2016, 643-644), because no instances were found in the translation or quotation of the Holy Scriptures.

13 This is the exact distribution among the different domains: 1. religious (a. theological writings, b. hagiographies, c.commentaries to the Holy Scriptures, d. Concilia, canones, regulae and alike), 107 times; 2. technical (a. juridical, b. veterinary, c. medical sources), 24 times; 3. epistolary, 17 times; 4. historical, 14 times; 5. didactic (1. scholiasts, 2. grammarians), 11 times; 6 . poetry, 8 times.

${ }^{14}$ The use of absolute ablatives is quite common in these two texts, both with present and perfect participles. In particular, Egeria resorts ten times to the pattern Deo iubente, in which the participle could have been in principle replaced by faciente (see n. 11 above)

15 See also below our commentary on Jordanes' passage (19). 
(2) quia faciente Deo tuam calcemus ut lutum potentiam (Lucif. De non parc. 9)

"Because with God's help we shall tread your power as mud."

He thus concludes that faciente-syntagms are by no means unusual, but they only provide evidence of the "augmented verbal force" of absolute constructions in later Latin. ${ }^{16}$ This explanation, though interesting, appears questionable on several grounds. First, nominal absolute ablatives never disappear from written language. For instance, aliquo adiutore and aliquo auctore are documented more than 160 and 280 times, respectively, in the Brepols' corpus between the $3^{\text {rd }}$ and $8^{\text {th }} \mathrm{c}$. AD. ${ }^{17}$ Second, such syntagms typically refer to a person or a god, while faciente, as we shall see below, is much more frequently found with inanimate subjects. Third, and most importantly, Flinck-Linkomies only suggests one factor that may have contributed to the origin and spread of the syntagm but does not explain why specifically facio was chosen as a verb within it. Probably, the main reason is thus to seek in the multifunctionality and polysemy of the verb that, in addition to the original value of "making", "producing", "creating" etc., could convey already in classical times several other meanings, such as "acting", "being active", "taking action". Furthermore, it may be governed by both animate and, less frequently, inanimate subjects, with various degrees of control over the action. ${ }^{18}$ Moreover, the verb is often followed by $u t+$ subjunctive (less frequently the subjunctive alone) or an infinitive clause, with the causative meaning of "bring about", "cause to happen", "let happen", etc. (cf. TLL VI 104, 53-106, 37). In such instances, documented throughout Latinity, the subject may be both animate and inanimate, ${ }^{19}$ as in Plaut. Stich. 177 paupertas fecit ridiculus forem ("poverty caused my being funny", transl. Loeb). It is hence possible that behind a sentence as Cassiod. In psalm. 89 si illi iniquitate sua faciente dispersi sunt ("if they were ruined because of their wickedness") some speakers may have recognized the pattern si iniquitas fecit, ut illi dispersi sint (or disperderentur) ("if the wickedness caused/brought them to be ruined"), with iniquitas identified as the main cause of the matrix clause. A hint in this direction is found in two late papyri from Ravenna approximately written in the same years:

(3) signum $\dagger$ Wiliarit clerici, $s$ (upra)s(crip)ti uenditoris, qui facien[te] inuecillitate oculorum suscribere non potuit ideoque signum f[ecit $]^{20}$ (Papyr. Tjäder 2, 34 1. 92, $551 \mathrm{AD}$ ).

"the Cross mark of priest Wiliarit, above-mentioned salesman, who, due to a disease of his eyes, could not sign and therefore put the (Cross) mark".

16 "Itaque nullo alio nomine nova est haec elocutio, nisi quod de aucta verbali absolutae elocutionis vi est testimonio" (Flinck-Linkomies 1929, 221).

17 It should also be observed that already in archaic and classical Latin these syntagms were not common. In the period between $200 \mathrm{BC}$ and $200 \mathrm{AD}$ (Aetas Antiquissima in the Brepols' database) we recorded less than 25 instances of adiutore, 3 of suasore and 2 of impulsore.

18 See the recent contributions by Fruyt $(2018,16-23)$ and Galdi $(2018,244-254)$. Ancient authors were certainly aware of the polysemic nature of the verb, as it emerges, for instance, from this passage of the jurist Papinianus (dig. 50, 16, 218) uerbum 'facere' omnem omnino faciendi causam complectitur dandi, soluendi, numerandi, indicandi, ambulandi ("the word facere embraces entirely all sorts of "doing": "giving", "paying", "reckoning", "declaring", "walking").

19 Cf. Fruyt $(2018,21-22)$.

20 The same expression is also found at 1. 92: signum $\dagger$ Vitaliani praesb(yteri) s(upra)s(crip)ti uenditoris, qui f[acien]te inuecillitate oculorum suscribere non potuit, signum $\mathrm{f}[\mathrm{ecit}]$. 
(4) faciente nequissima egritudine polagrae, quia suscribere non potui, signum tamen be[at] ạe crucis, ụt potui, coram testibus inpressi (ibid. 1, 4-5 B VII, 1. 3, 552-575 AD)

"since/although the terrible disease of goat caused that I couldn't sign, yet I impressed the mark of the Holy Cross, as far as I could, in front of testimonies".

As observed by Tjäder $(1982,274)$ the two papyri were written by the same scribe, i.e. Deusdedit. In (3) we read that due to an illness of the eyes the salesperson was not able to subscribe the document and therefore put the sign of the Cross on it. Similarly, in (4) a man reports that although the gout didn't allow him to sign the text, he marked it with the Holy Cross. ${ }^{21}$ Now, while in the first case the standard faciente-syntagm occurs (faciente inuecillitate oculorum), with a clear causal force, in (4) the scribe, though resorting to a very similar pattern (faciente egritudine polagrae), converts the syntax into a causative structure by adding the subordinate quia-clause (faciente ... quia subscribere non potui). ${ }^{22}$

\section{Categorial shifts of participles}

The recategorization of participles and their shift into the prepositional class represents a well-known phenomenon typically associated with the more general grammaticalization process by which content/lexical items develop into function/grammatical items. ${ }^{23}$ A reference paper on deverbal prepositions in European languages, including Latin, is that by Kortmann and König (1992). They observe, among other things, that prepositions deriving from verbal forms on the one hand "are marginal in their lexical class" on the basis of several criteria such as low frequency, number of syllables, conservation of verbal properties etc., and, on the other hand, constitute an "extremely heterogeneous group" whose members share different properties. In particular, referring to English, they recognize a scalarity with respect to the degree of reanalysis, as shown on figure 2 (Kortmann, König 1992, 684):

\begin{tabular}{llllc}
\multicolumn{2}{c}{ lowest degree } & \multicolumn{2}{c}{ highest degree } \\
\cline { 2 - 5 } \multicolumn{1}{c}{ facing } & considering & according to & during & past \\
lining & failing & allowing (for) & pending & ago \\
preceding & barring & owing to & except & bar \\
succeeding & following & notwithstanding & concerning &
\end{tabular}

Fig. 2. Gradient with respect to the degree of reanalysis of participles as prepositions

The items on the left are those that exhibit a higher degree of "verbiness" and, therefore, "can be categorized as prepositions only in certain, but not in all of their uses", while

${ }^{21}$ Here, the use of tamen in the main sentence makes a concessive reading of faciente more plausible ("despite the disease of goat, nevertheless I could sign").

${ }^{22}$ Incidentally, it should be observed that the syntagm facio quia corresponding to facio ut (or infinitival clause) is unknown elsewhere. The TLL and Hofmann, Szantyr (1972) report no examples of the construction and we couldn't find any parallel in the Brepol's corpus.

${ }^{23}$ For bibliographic references, cf. Brinton (2012) and Rovai $(2013,176)$. 
those on the right are characterized by a higher degree of reanalysis and are thus closer to the nominal pole.

As for Latin, deverbal prepositions constitute all in all a relatively rare category (Lehmann, in print). Some of the most common ones, i.e. praesente, absente, stante, excepto, excluso and anteposito have been recently investigated by Rovai (2013), who quotes several examples. ${ }^{24}$ As a framework, Rovai adopts the "Non-discreteness hypothesis of Parts of speech", which considers word classes as flexible lexical categories definable on the base of given morphological, syntactical and semantico-pragmatic properties ${ }^{25}$. These categories are "established language-specifically over a continuum, whose cornerstones are the prototypes of noun and verb" and "they are connected by the two scales of increasing nouniness/decrasing verbiness and decreasing nouniness/increasing verbiness", according to the following schema (Rovai 2013, 181):

\section{PROTOTYPICAL NOUN}

Noun Adjective

[+ nouniness]

[- verbiness]

\author{
PROTOTYPICAL \\ VERB \\ Verb \\ [- nouniness] \\ [+ verbiness]
}

Preposition

Participle

Fig. 3. The Noun-Verb continuum

According to the figure, there exists no clear-cut division between prepositions and participles, but they represent scalar categories "whose prototypes combine both verbal and nominal features in different degrees, whose boundaries are fuzzy, and in which membership is a matter of gradience" (Rovai 2013, 181). The recategorization of participles as preposition represents hence a spread phenomenon in the world's languages, but the specific reasons behind it are not always clear-cut. According to Rovai, the main factor triggering the reanalysis of participles in Latin, as well as in other world's languages, lies in the semantics of the verbs they derive from, which all exhibit at least one of two features that drastically contribute to decrease their "verbiness", shifting them towards the nominal pole. These are (a) "non-factuality" (absente "in the absence of", excepto, excluso "leaving aside, barring", etc.) and (b) "time-stability" (the participles chiefly derive "from the most stative, i.e. the least prototypical verbs" ${ }^{26}$ ). Additionally, Rovai notices that proper transcategorization only takes place if two changes surface at the mopho-syntactic level, i.e. loss of number agreement with the noun (thus, participle in the singular and noun in the plural), and stable word order reversion, from verb-final to verb-initial. ${ }^{27}$ Both features are exemplified in (5), (6):

${ }^{24}$ In his contribution of 2014, Rovai also includes praesidente in the discussion.

25 Cf. Sasse (2001). See also Rovai $(2013,181 ; 2014,488)$ with further references.

26 Cf. Rovai $(2013,199)$.

27 Cf. also Kortmann, König (1992, 674-676). Note, however, that the rigidification of the word order V-N, though nearly systematic, does not always occur. In English, for instance, the deverbal preposition "notwithstanding" can be found in both sentence-initial and sentence-final position, as in the two examples reported by Kortmann, König $(1992,675)$ : a. We did it, his objections notwithstanding and b. We did it, notwithstanding his objections. 
(5) nec praesente nobis alius quisquam est seruos Sosia (Plaut. Amph. 400)

"And when the two of us are present, there's no other slave Sosia" (transl. Loeb).

(6) stante ista omnia, quod super(ius) diximus (Chartae Lat. ant. 13, 571, 690-691 AD)

"Given all these things that we mentioned above".

\section{The evolution of faciente and its shift into the prepositional class}

If we now apply the morpho-syntactic and semantico-pragmatic conditions posed by Rovai to the faciente-syntagms, we easily recognize that most of them are not fulfilled. Therefore, one cannot speak of a real or complete transcategorization of the participle. To begin with, at the semantico-pragmatic level - which, according to Rovai, constitutes the most important factor triggering the categorial reanalysis - facio displays very different properties as compared to excepto, absente and analogous participles. As seen above, it is typically characterized by strong agentivity features (animacy of the subject, dynamicity, change of state, etc.) and it is, consequently, high in "verbiness". ${ }^{28}$ Additionally, faciente expresses nearly systematically the cause or reason lying behind the main predicate ${ }^{29}$ and is consequently involved in the innermost layer of the matrix clause. Conversely, prepositions like excepto, praesente and alike provide more marginal information and are rather related to the periphery of the main clause. ${ }^{30}$ Concerning word order, there is a clear dominance of the classical N-V, not only in absolute terms (128 times, that is, $70 \%$ of the totals) but also in relation to the single periods and genres. Furthermore, agreement errors are extremely rare: we annotated only seven instances in which the participle, the noun or both are in the accusative case, (some of these, as (7), may easily be put down to a scribal error), e.g.

(7) taliter fuit professus, quod faciente inimicum ipsum hominem occidisset (Formul. Sal. Bignon. 9, $8^{\text {th }}$ c.)

"he admitted that he had killed the man under the enemy's influence"

(8) si quis hominem liberum casum facientem nolendo occiderit (Edict. Roth. $387,7^{\text {th }}$ c.)

"if someone killed accidentally and unintentionally a free person".

Of these, however, only one (9) involves number agreement and may thus be considered representative of a reanalysis process (note here, though, the standard word order $\mathrm{N}-\mathrm{V})$ :

(9) quae unus de fidelibus ac leodebus... interrigna faciente uisus est perdidisse (Edict. Cloth. p. $285,7^{\text {th }}$ c.)

"the possessions that one of his servants or subjects has lost because of the partition of the Kingdom".

28 See Baños Baños (2016, 9 n. 21) and Galdi (2018, 245).

29 Among the very few exceptions is the cluster casu faciente (on which see below), which bears rather a modal meaning ("by chance").

30 The same applies to the deverbal prepositions analysed by Kortmann and König $(1992,691)$. 
Finally, this use is not confined to the singular: we annotated 41 absolute ablatives with the plural facientibus fulfilling the same conditions posed for faciente (i.e. occurring within an absolute ablative and without adverbial or prepositional determinations). ${ }^{31}$ This represents, though, a very formulaic use, because it is only found in Christian authors and is almost entirely restricted to peccatis ( 34 times) or to semantically related nouns, ${ }^{32}$ e.g.

(10) dum peccatis nostris facientibus morimur, eius clementiae remissione saluamur (Cassiod. In psalm. 41)

"while we die because of our sins, we are rescued by the forgiveness of his mercy".

(11) ecclesia Tadinatis ... est delictis facientibus hostili feritate occupata atque diruta (Gregory the Great epist. 1, 77)

"the church of Tadinum, due to its crimes has been occupied and destroyed by the hostile savageness".

Now, despite the four factors outlined above (high "verbiness" of the participle, (nearly) no agreement errors, strong dominance of the word order $\mathrm{N}-\mathrm{V}$ and use of the plural), important clues reveal that faciente is used in a peculiar way in our syntagm, and some of them point to a partial transfer into the class of prepositions. First, in its prototypical uses, facio is accompanied by one or more arguments and/or satellites and is governed by an animate - generally human - subject exerting control on the action. According to the facio-lemma in the TLL, the absolute use of the verb, i.e. without adverbial or prepositional determinations (as in our syntagm), is not common. More specifically, if we confine our attention to the instances with inanimate subject, the figures drastically drop: of the nearly 4300 lines making the $T L L$-article, only 29 (roughly $0,7 \%$ ) are devoted to this use and some of them don't even count because they include adverbs of manner ("nude vel cum adverbio modi", TLL VI 122,12). Conversely, in the analysed corpus, 115 examples of faciente, that is, almost two thirds of the totals, are governed by an inanimate subject. Interestingly, a diachronic analysis shows that this type of nouns significantly increases in later centuries, as represented on fig. 4:

Of the 75 instances found until the end of the $5^{\text {th }}$ century, 49 (thus, $65 \%$ ) involve animate subjects, which is in line with the classical uses of the verb. Specifically, 39 of these refer to divine entities, such as Deus, Iesus Christus, diabolus (cf. [2] above). On the contrary, the same is true for only 17 (thus, $16 \%$ ) of the 106 occurrences found in the later period. Correspondingly, the incidence of cases with inanimate subjects increases from $35 \%\left(1^{\text {st }}-5^{\text {th }}\right.$ c. $)$ to $84 \%\left(6^{\text {th }}-9^{\text {th }} \mathrm{c}\right.$. $)$. Of course, in most of these instances, no direct control of the subject can be assumed, as in (12).

(12) sexta ceruice feratur: lectica enim faciente luxuria a sex hominibus portabatur (Schol. Iuv. $1,64)$

"he is carried on six necks: for, due to luxury, the litter was carried by six persons".

31 Interestingly, this type is not mentioned in any study dealing with faciente (see section 1 above).

32 Additionally, the use of facientibus is quite late. I only recorded five instances before the $6^{\text {th }}$ century. 


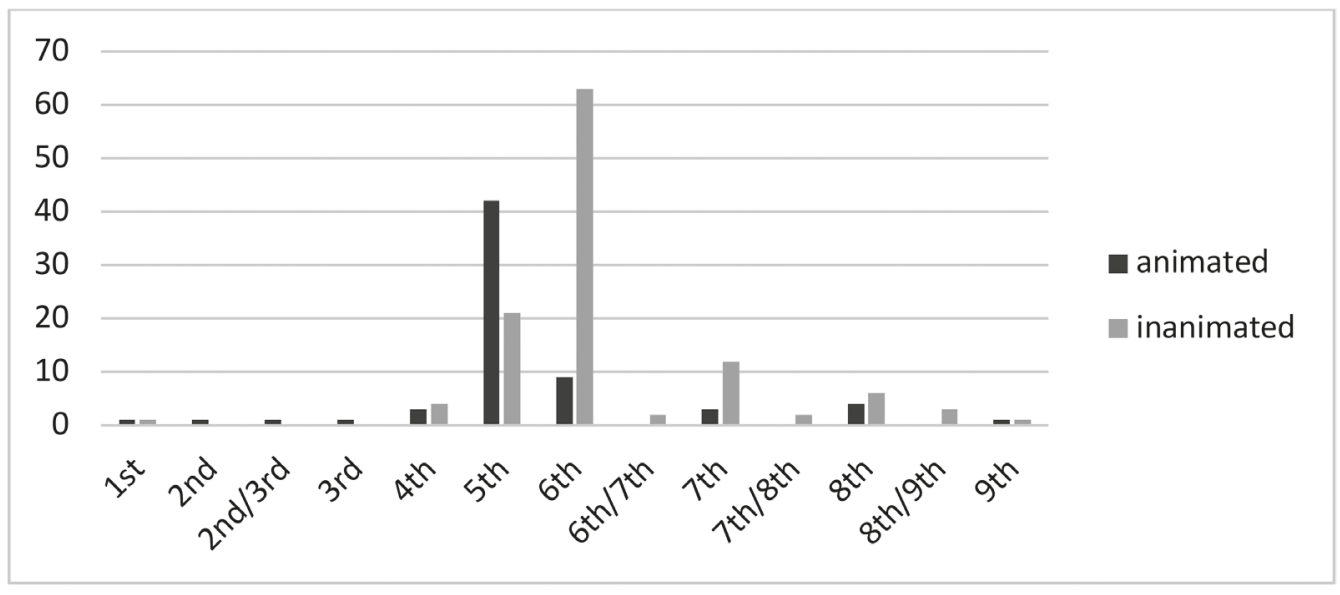

Fig. 4. Diachronic distribution of subjects' animacy

The picture becomes though more accurate if one considers the type of inanimacy of the subject. To this purpose, we made a distinction between two equally large classes of inanimate nouns exhibiting the same diachronic distribution (ca. $20 \%$ until the $5^{\text {th }} \mathrm{c}$. and ca. $80 \%$ from the $6^{\text {th }}$ c. onwards).

(A) (52 instances) Nouns expressing a human or divine property, action, condition or part of the body (superbia, frugalitas, duritia, lingua etc.), behind which one may recognize an intentional choice, attitude or responsibility of an animate entity. For instance, in (12) luxuria is not conceived by the Scholiast as a purely abstract property, but as the result of a deliberate attitude of the forger who is carried on the litter. A similar consideration applies to odio (13) and obliuione (14) below, for in both cases we may assume an involvement or responsibility of the persons to whom they are associated (Theophilus and the author himself, respectively):

(13) hunc Theophilus ab ecclesia odio faciente proiecit (Cassiod. hist. 10, 10, 9)

"Theophilus expelled him from the church out of hatred."

(14) faciente nostra obliuione (epistula) apud quem remanserit ignoramus (Ferrand. epist. $13,3)$

"Due to our forgetfulness, we ignore who is now in possession of the letter."

In all such cases, despite the inanimacy of the subjects, a degree of control or, at least, involvement of the animate entity 'behind' them can reasonably be guessed.

(B) (53 instances) Nouns denoting a human or non-human property, state or (rarely) object that falls entirely outside the control of animate entities. Particularly remarkable, here, are instances with casus (8), (17), necessitas (15), mors (16) and alike, which clearly rule out any form of human responsibility or involvement.

(15) quia singulis, ut solebam faciente necessitate scribere non potui (Euseb. Verc. Epist. 2, 11)

"because, forced by necessity, I could not reply to the single letters, as I used to do". 
(16) qua (morte) faciente (pater) funus filii non potuit cernere (Schol. Stat. Theb. 8, 651-652) "due to his death (= since he was dead), the father could not attend the funeral of the son".

Interestingly, in some texts faciente occasionally alternates with the simple ablative of the name it is in agreement with, without any remarkable difference. Compare, for instance, (17) with (18), both taken from Cassiodorus' Expositio psalmorum:

(17) in derogatione alterius non casu aliquo faciente dilapsus est, sed diutinus fratris sui de tractor insedit (Cassiod. In psalm. 49)

"He did not lapse accidentally into the calumny of another person, but he kept acting for a long time as a slanderer of his brother."

(18) fieri enim potest ut homo sanctus casu aliquo ad concilium ueniat iniquorum (ibid. 25)

"for it can happen that a holy man accidentally joins a gathering of evil persons".

Such cases are revealing of a desemanticization of the participle ${ }^{33}$ that appears to be used for functional rather than for semantic reasons. ${ }^{34}$ Of special interest, in this regard, is the following passage from Jordanes' Romana:

(19) Adrianus morbo apud Baias faciente obiit (Iord. Rom. 270). ${ }^{35}$

"Hadrian died because of an illness at Baia."

As it is well known, Jordanes bases its works on a large variety of sources and he often adapts their language either on merely stylistic grounds, or in order to make it more explicit and 'accessible' for the average reader of the mid- $6^{\text {th }}$ c. AD. ${ }^{36}$ In (19) the model, i.e. Jerome's Chonicon, reads, Hadrianus, morbo intercutis aquae aput Baias moritur (chron. a.Abr. 2153). Jordanes on the one hand shortens the text, omitting the type of sickness and the death age of the emperor, but on the other hand extends it, specifying the causal/ instrumental function of morbo with faciente, which does not convey any discernible semantic value. ${ }^{37}$

The probably best piece of evidence in support of the desemanticization of faciente and, above all, of its functional evolution towards the prepositional pole is found in a longer passage from Augustine's sermons which found so far no attention in scholarly literature. We quote it at length:

33 This process was first noticed by Heraeus $(1903,466)$, who speaks of pleonasm: "In vielen dieser Beispiele ... ist faciente geradezu pleonastisch".

34 Semantic bleaching is one of the changes frequently accompanying the reanalysis of participles as prepositions. Cf. Kortmann, König (1992, 680-681).

35 Note that this occurrence was not included in the totals, because according to the word order faciente is determined by the prepositional phrase apud Baias and displays, hence, verbal function at the syntactic level. However, based on the text of Jerome (morbo intercutis aquae aput Baias moritur, see further) we cannot rulle out that apud Baias is linked, through hyperbaton, to obiit.

${ }^{36}$ Cf. Galdi (2010) with references.

37 Similarly, a few lines back in the same paragraph, the author replaces sponte propria ("spontaneously") of Rufinus, with nulla faciente necessitate ("even though there was no necessity"). 
(20) quotidie morior per uestram gloriam, fratres, quam habeo in Christo Iesu Domino nostro. per uestram gloriam iuratio est. non quasi sic ait: per uestram gloriam morior, quasi "uestra gloria me facit mori"; quomodo si diceret: "per uenenum mortuus est", "per gladium mortuus est", "per bestiam mortuus est", "per inimicum mortuus est"; id est "faciente inimico", "faciente gladio", "faciente ueneno", et similia. (August. Serm. 180)

"I die daily, (I protest) by your glory, brothers, which I have in Jesus Christ our Lord. Per uestram gloriam is an oath. He does not say per uestram gloriam morior with the meaning "your glory causes me to die"; as if he would say "he died because of poison", "he died because of a sward", "he died because of an animal", that is, "because of an enemy", "because of a sward", "because of poison", and similar."

Commenting on Paul's text quoted in italics (1 Cor. 15, 31), Augustine points out that per uestram gloriam is a form of oath ("by" or "in the name of your glory"). This is, in such a context, a fundamental remark, because, as observed by the author, due to the word order, per uestram gloriam may easily be misunderstood as the cause of the death (quasi "uestra Gloria me facit mori"). Obviously, such a reading would totally reverse the original sense of Paul's words. In order to clarify this point, Augustine zooms in the wrong interpretation, giving, as example, three sentences with per + noun + mortuus est, in which the causal/instrumental function of the preposition appears evident. He then glosses these expressions by replacing the prepositional clusters with our syntagm (faciente inimico, faciente gladio, faciente ueneno). Three central remarks should be done here. First, and most importantly, Augustine considers in this context the causal/instrumental cluster per + accusative as semantically equivalent and thus interchangeable with faciente. This provides us decisive evidence for an at least partial reanalysis and transfer of the participle into the domain of prepositions. Second, two of the three instances with faciente involve inanimate nouns (gladio, ueneno). Since Augustine adopts the construction for merely exegetic purposes (he wants to be sure that per uestram gloriam is not interpreted the wrong way), we have to assume that the average reader and/or listener of his time would have readily understood what he meant. Hence, it is likely that the combination of faciente with non-animate subjects was already common by that time (beginning of the $5^{\text {th }} c$.), even though it first spreads, in written sources, from the $6^{\text {th }}$ c. onwards (see fig. 4 above). Third, it is noteworthy that per is glossed with faciente, because there were at least three other prepositions perfectly apt to express the cause in this context, that is, ob, propter and prae. ${ }^{38}$ Now, given that the Sermones were conceived for an oral delivery directed to a multifarious audience and their style was thus presumably "not too far removed from that of the normal speech" (Herman 2000, 24), we can legitimately assume that this use of faciente was commonplace at that time, possibly even among lower social classes. ${ }^{39}$

${ }^{38}$ Additionally, in late Latin the ablative of cause is often replaced by ex, de and in. Cf. Hofmann, Szantyr 1972, 134.

39 Another less explicit, but still instructive passage is found in Fulgentius (praedest. 3, 17). Here the author alternates, without any apparent semantico-pragmatic difference, faciente and propter within the same context: an forte dicitur cordis illorum duritia faciente Saluatorem nostrum suae agnitionis aperire noluisse mysterium? ... illos ... quibus (Christus) propter duritiam cordis eorum nolebat suae agnitionis aperire mysterium "may somebody perhaps say that our Saviour didn't want to unveil the mystery of his knowledge because of the harshness of their hearts? ... those ... to whom Christ didn't want to unveil the mystery of his knowledge because of the harshness of their hearts". 
Summing up, the results discussed above reveal both a relatively spread use of $f a$ ciente, especially after the $4^{\text {th }} \mathrm{c}$. $\mathrm{AD}$, and a diachronic change. Until the $5^{\text {th }} \mathrm{c}$., it mainly refers to animate (notably divine) entities $(65 \%)$, while in the later period inanimate subjects become strongly dominant (84\%). Accordingly, we observe on the one hand a decrease of control of the subject over the participial action and, on the other hand, a semantic weakening of the verb, which often appears redundant. Both aspects are particularly evident with nouns as casus, necessitas etc., for which no form of control can be assumed (see group (B) above). This evolution points to a partial grammaticalization of the participle: in several - especially later - instances, faciente loses, to a large extent, its classical meaning, apparently fulfilling a pure grammatical function as a marker of the causal or instrumental value of the noun it agrees with. ${ }^{40}$ Example (20) above, where causal per is glossed with faciente, confirms our hypothesis. However, as opposed to other, more common deverbal prepositions such as absente, excepto etc., this development does not become "visible" at the morpho-syntactic level - through loss of agreement or inverted word order - but remains restricted to the semantic domain.

A suitable theoretical framework to describe this process is the grammaticalization model of semantic change proposed by Heine (2002), which "rests on a clear-cut division between context and meaning" (Heine 2002, 86). Heine outlines a "scenario of how a linguistic expression acquires a new grammatical meaning" ( $i b$.), assuming four subsequent stages that develop over a continuum. For each stage, Heine indicates a specific context and a resulting meaning, as shown in fig. 5 (cf. Heine 2002, 86):

Stage

I Initial stage

II Bridging context

III Switch context

IV Conventionalization

\section{Context}

Unconstrained

There is a specific context giving rise to an inference in favor of a new meaning

There is a new context which is incompatible with the source meaning

The target meaning no longer needs to be supported by the context that gave rise to it; it may be used in new contexts

\section{Resulting meaning}

Source meaning

Target meaning

foregrounded

Source meaning

backgrounded

Target meaning only

Fig. 5. Grammaticalization model of semantic change

At the first stage, the source (or original) meaning occurs in unconstrained contexts. At stage II, there appears a bridging context: the source meaning cannot be ruled out, but the target meaning offers "a more plausible interpretation of the utterance concerned".

40 Significantly, in nearly all instances the participle and the nominal head or its modifiers, are a in contiguous position. There are only seven exceptions, of which three within the syntagm faciente ac suscipiente uerbo: two of these, though, are quotations from Augustine: nonne faciente ac suscipiente Verbo, ipse homo ... filius Dei unicus esse coepit? (praed. sanct. p. 982) "wasn't through the mediation and support of the Word that the man started being the unique son of God?". 
Stage III is characterized by a switch context "that no longer allows for an interpretation in terms of the source meaning". This leads to the final step, in which the target meaning appears "freed of the contextual constraints that gave rise to it" and is therefore conventionalized. ${ }^{41}$ In the case of faciente, due to the lack of morpho-syntactic clues, the context can only be defined in relation to the type of noun subject. Specifically, we must consider both the animacy of the noun and the degree of control over the participial action. The different stages are exemplified in (21)-(23)

(21) si (mancipium) contra legem uenditionis faciente te ad libertatem peruenerit (Pompon. Dig. 21,2,34)

"if the slave shall come to freedom through your help against the sale law".

(22) ab his, quae tibi inminent, faciente Dei auxilio libereris et misericordia (Arnob. Iun. Confl. $2,29)^{42}$

"you shall be freed by the things that threaten you through the help and mercy of God".

(23) pauperibus uel infirmis, qui debilitate faciente non possunt suis manibus laborare (Conc. Aurel. a. 512, p.9)

"to the poor and ill people that cannot work with their hands because of an illness".

Instances as (21), characterized by [+ animacy] and [+ control] of the subject illustrate the first stage, in which facio fully preserves its source meaning of "acting", "operating" (cf. also (2), (7)). Accordingly, in such cases, as opposed to (22) and (23), the omission of the participle would make the sentence unintelligible (e.g. ${ }^{\star}$ te ad libertatem peruenerit). Example (22) is representative of stage II: the subject is inanimate, but since it expresses a divine action (auxilio) and property (misericordia), we can assume (to different extents) a form of control behind it (cf. (12)-(14) above) ${ }^{43}$. The source meaning of facio is still recognizable, but the target one is now foregrounded. Finally, instances as (23) which, in addition to the inanimacy of the noun, exclude any form of control on the verbal action, ${ }^{44}$ are suggestive of stage III. There is a switch context, incompatible with the source meaning, and facio, while semantically redundant, appears as a grammatical marker of the instrumental/causal function of the noun in agreement. Our syntagm never achieved the last stage outlined by Heine, because in that case we would reasonably expect a rigidification of both the singular faciente and the word order V-N (e.g. ${ }^{*}$ faciente peccatis, ${ }^{*}$ faciente occasionibus etc.). ${ }^{45}$ The main reason why the evolution did not go beyond stage III has to be sought in the semantics of facio. As explained by Rovai, the triggering factor behind the categorial reanalysis of participles as prepositions probably lies in semantico-pragmatic factors, namely the "non-factuality" and/or "time-stability" of the underlying verbs, which situates them closer to the nominal pole. On the contrary, in its standard uses, facio

${ }^{41}$ Note that in principle all stages may synchronically coexist side by side as "contextually defined variants" (Heine 2002, 86).

${ }_{42}$ This is the only instance in which two nouns governing faciente are kept apart by the main predicate.

43 The same applies to the class of inanimate nouns outlined above under (A).

${ }^{44} \mathrm{Cf}$. the class of nouns (B) above.

45 As observed above, the plural facientibus keeps on being used until the latest centuries, although it is essentially confined to peccatis and synonymic words. 
exhibits high agentivity features, and its degree of "verbiness" is therefore marked. Due to the very common use of the verb throughout the history of Latin ${ }^{46}$ (and, later, in the Romance languages), speakers remained certainly aware of these properties. Additionally, prototypical deverbal prepositions as absente, excepto etc., generally develop where core prepositions are lacking (Kortmann-König 1992, 690; Rovai 2013, 184), while the instrumental/causal function of faciente could be expressed by several prepositions or even by simple case-marking.

\section{Relation with semantically contiguous syntagms}

Before moving to the conclusions, let us briefly look at the relation between faciente and similar constructions with present participle largely attested in the late centuries, such as instigante, fauente, operante etc. + nominal head. Several scholars mention these syntagms in connection with faciente, regarding them as nearly synonymic choices. FlinckLinkomies, for instance, referring to our syntagm claims: "[non] secernenda est ex aliis, quae saepissime obviam fiunt apud inferioris aetatis scriptores, in quibus participia praesentia variorum verborum similiter in absolute usu adhibentur" $(1929,221) .{ }^{47}$ Similarly, Horn (1918, 35-39) includes these participles within the formulaic absolute ablatives, and Hofmann, Szantyr $(1972,133-134)$ discuss them all together in the same paragraph (" $f a$ ciente, operante u.ä").

We have restricted our analysis to opero, instigo and praesto both because of their semantic affinity with facio and of their spread use in the late centuries. For each verb, we annotated all the instances found in the Library of Latin texts A and B between the $3^{\text {rd }}$ and $8^{\text {th }}$ c. AD.

Of the three verbs, opero is the one semantically closest to facio. The participle operante, despite its relatively high frequency (111 times, from Tertullian onwards), displays important differences to faciente. First, its use is mainly attested in religious works (92 times, thus $83 \%$ ), especially theological treatises and commentaries, and it is never found in technical texts. Additionally, ca. $40 \%$ of the examples are found within three recurring clusters with gratia (14 times), Deus and Spiritus (both 15 times), while faciente exhibits a much larger variety of nouns. ${ }^{48}$ Second, inanimate subjects are not as common (52 times, thus $47 \%$ of the totals as against $64 \%$ with facio), and more than the half refer to divine properties (especially gratia), behind which we can assume a form of control ${ }^{49}$. More generally, divine entities or properties constitute the subject in almost three fourths of the totals (81 times) as against less than one third with facio (54 times). The verbal character appears thus much more prominent with operante than with faciente and this is confirmed by the fact that in 52 instances not included in the totals the participle is accompanied by a prepositional phrase or an adverb, ${ }^{50}$ e.g. operante ... et proficiente usque

${ }^{46}$ Cf. Fruyt 2018, 16-17.

47 He refers, here, among the others, to (co)operante, dispensante, instigante and praestante.

48 As observed above (n. 11) recurring clusters are not common with this participle. Two exceptions are represented by Deo faciente and casu faciente (both 10 times).

49 See the class of names (A) in section 6.

50 Conversely, this is only five times the case with faciente (see n. 9). Note also that in 23 occurrences (21\%) operante is coordinated to another present participle displaying standard verbal function. This phenomenon is much less common with faciente (13 times, thus, $7 \%$ ). 
in finem gratia Dei (Tert. De virg. 1) "as long as the grace of God is at work and advances until the end".

The results found with operante apply even more to instigante (57 occurrences) and praestante (283 times). Both participles are mainly concentrated in religious, notably theological texts and their subject is in far most of the instances $(79 \%$ and $94 \%$, respectively) an animate - generally divine - entity deliberately performing a controlled action. Particularly spread are the four clusters diabolo instigante (29 times), Domino praestante (118 times), (Iesu) Christo praestante (79 times) and Deo praestante (43 times), which became, at a large extent, stereotyped expressions. ${ }^{51}$

To sum up, despite the undeniable similarities, ${ }^{52}$ significant divergences emerge between the constructions with faciente and those with operante, instigante and praestante, and the same is most likely true for other, semantically contiguous participles. For one thing, the former is spread over different genres and registers, even in technical texts, while the latter are mostly confined to religious sources, often within formulaic phrases. For another thing, and more to our point, inanimate subjects and, consequently, lack of (direct) control characterize most of the occurrences of faciente, whereas animate nouns gain the upper hand with operante and, even more, with instigante and praestante. Our data point thus to the conclusion that these participles, as opposed to faciente, did not undergo any reanalysis process, retaining their verbal force until the latest centuries. A crucial element that contributed to this difference is to seek in the polysemy and multifunctionality of facio, which could already in classical times be employed in a large variety of contexts and was often associated with inanimate subjects.

\section{Conclusions}

In this contribution, we discussed the instrumental/causal use of faciente + (pro)nominal head without adverbs or arguments in a large corpus including both non-literary and literary sources. The analysis lead to three central results. First, the construction is relatively well represented in the corpus, with 182 instances, from Ovid onwards, reaching its peak in the $5^{\text {th }}$ and $6^{\text {th }} \mathrm{c}$. AD and surviving until the late medieval period. Additionally, a notable variety emerged in terms of both nouns involved (100 in total) and literary genres and registers (see n. 13) and we may not rule out the possibility that the syntagm found its way in some spoken varieties of the language. Second, a lexical and semantic analysis of the nouns involved reveals that the participle underwent a partial categorial reanalysis as preposition. This process becomes evident through (a) the use of inanimate subjects (superbia, militia, peccatum, etc.), notably such as casus, necessitas, egestas, tempus etc. which exclude any form of control by a human or divine entity and (b) an explicit testimony found in Augustine's sermons (20), where faciente is used as an equivalent of the causal pattern per + accusative. Specifically, taking as reference point the grammaticalization model proposed by Heine (2000), we assumed that the evolution of the participle reached

${ }^{51}$ In particular, the three above-mentioned expressions with praestante are chiefly used after the matrix clause as stock-phrases, often within dialogic contexts, as in English "with God's help", "with the assistance of God", e.g. August. Serm. 272B obliuiscamur aliquando terram ut de terra in caelum leuari mereamur praestante Domino nostro Iesu Christo ("let us once forget the earth in order to deserve to be raised from earth to heaven with the help of our Lord Jesus Christ").

${ }^{52}$ Note for instance that Dominus and misericordia are found as subject of all four participles without remarkable semantic differences. 
stage III, characterized by a "switch context ... that no longer allows for an interpretation in terms of the source meaning". However, the non-generalization of the word order V-N, which stably remains much less common than $\mathrm{N}-\mathrm{V}$, and of the singular faciente (the plural facientibus is found 41 times) show that the development never attained the fourth and final stage of Heine's model, in which namely the target meaning is conventionalized. We cannot therefore speak of a proper, or full transcategorization of the participle and the reason for that is most likely to be sought in the semantic nature of facio, which prototypically displayed high agentivity features and was thus "unbalanced" towards the verbal pole. Finally, the analysis has shown that the three participles operante, instigante and praestante, often regarded in studies as synonymic alternatives to faciente, differ from it in at least two aspects. On the one hand, they are mainly restricted to Christian sources and are very often found in recurring clusters, such as Deo praestante, diabolo instigante, or Spiritu operante. On the other hand, and more importantly, the type of nouns involved indicates that they generally remained high in "verbiness" and did not thus undergo any reanalysis process. The latter difference has been crucially fostered by the fact that facio, as opposed to other verbs, kept throughout Latinity a high degree of polysemy and multifunctionality and could hence be employed in a large variety of contexts with both animate and inanimate subjects.

\section{References}

Adams J.N. An anthology of informal Latin (200 BC - AD 900). Cambridge, Cambridge University Press, 2016.

Baños Baños J.M. Algunas consideraciones sobre los verbos soporte en latín: Sintaxis y semántica, in: E. Borrell Vidal, Ó de la Cruz Palma (eds). Omnia mutantur II. Canvi, transformació i pervivència en la cultura clàssica, en les seves llengües i en el seu llegat. Barcelona, Edicions de la Universitat de Barcelona, 2016, 3-27.

Brinton L. J. "The ghosts of old morphology": Lexicalization or (de)grammaticalization?, in: K. Davidse, T. Breban, L. Brems, T. Mortelmans (eds). Grammaticalization and Language Change. New reflections. Amsterdam/Philadelphia, John Benjamins, 2012, 135-166.

Flinck-Linkomies E. De ablativo absoluto quaestiones. Helsinki, Annales Academiae Scientiarum Fennicae, 1929.

Fruyt M. L'expression de la causativité en latin dans la perspective de l'évolution linguistique, in: A. Thibault, M. Duval, N. Lo Vecchio (eds). Le causatif: prospectives croisées. Strasbourg, Éditions de linguistique et de philologie, 2018, 9-43.

Galdi G. On the use of facio as support verb in late and Merovingian Latin. Journal of Latin Linguistics 2018, 17 (2), 231-257.

Galdi G. Late sparsa collegimus: the influence of sources on the language of Jordanes, in: E. Dickey, A. Chahoud (eds). Colloquial and Literary Latin. Cambridge, Cambridge University Press, 2010, 357-375.

Heine B. On the role of context in grammaticalization, in: I. Wischer, G. Diewald (eds). New reflections on grammaticalization. Amsterdam, John Benjamins, 2002, 83-101.

Heraeus W. Die Sprache des Petronius und die Glossen. Leipzig, Teubner, 1899.

Heraeus W. Sprachliches aus den Pseudoacronischen Horazscholien. RhM 1903, 59, 462-467.

Herman J. Vulgar Latin. Penn State, University Press, 2000.

Hofmann J. B., Szantyr A. Lateinische Syntax und Stilistik. Teil 2. Bd. 2. München, C. H. Beck Verlag, 1972. Horn F. H. Zur Geschichte der absoluten Partizipialkonstruktionen im Lateinischen. Lund, Gleerup, 1918.

Kortekas G. A. A. Commentary on the Historia Apollonii Regis Tyri. Leiden - Boston, Brill, 2007.

Kortmann B., König E. Categorial reanalysis: the case of deverbal prepositions. Linguistics 1992, 30, 671-697.

Kropp A. Magische Sprachverwendung in vulgärlateinischen Fluchtafeln (defixiones). Tübingen, Narr, 2008.

Lehmann Ch. Complex spatial prepositions from Latin to Castilian, paper presented at the $49^{\text {th }}$ Annual Meeting of the Societas Linguistica Europaea (31/08-03/09/2016, Naples), in print. 
Löfstedt E. Philologischer Kommentar zur Peregrinatio Aetheriae. Untersuchungen zur Geschichte der lateinischen Sprache. Uppsala, Arbeten utgifna med Understöd af Vilhelm Ekmans Universitetsfond, 1911.

Panayotakis S. The Story of Apollonius, King of Tyre. A Commentary. Berlin - Boston, de Gruyter, 2012.

Rovai F. Da participi presenti a preposizioni deverbali: le basi semantiche della transcategorizzazione, in: P. Molinelli, P. Cuzzolin, Ch. Fedriani (eds). Latin Vulgaire Latin Tardif X. Actes du Xe colloque international sur le latin vulgaire et tardif (Bergamo, 5-9 septembre 2012). Bergamo, Sestante edizioni, 2014, 483-496.

Rovai F. The development of deverbal prepositions in Latin: morpho-syntactic and semantico-pragmatic factors. Archivio Glottologico Italiano 2013, 98 (2), 175-213.

Sasse H.-J. Scales between nouniness and verbiness, in: M. Haspelmath, E. König, W. Oesterreicher, W. Raible (eds). Language Typology and Language Universals. Berlin-New York, de Gruyter, 2001, 495-509.

Tjäder J.-O. Die nichtliterarischen lateinischen Papyri Italiens aus der Zeit 445-700. Band II: Papyri 29-59. Stockholm, Paul Åströms, 1982.

Received: March 2, 2019

Accepted: April 20, 2019 